\title{
The distinctive grave goods from Palhais (Beja, Portugal). New insights into the metallurgical evolution under Orientalizing influence in the southwestern end of Iberia
}

\author{
El ajuar de la necrópolis de Palhais (Beja, Portugal). Nuevos conocimientos sobre la \\ evolución metalúrgica bajo la influencia orientalizante en el extremo suroriental de Iberia
}

\author{
Pedro Valério (*) \\ António M. Monge Soares (*) \\ María Fátima Araújo (*) \\ Rui J. C. Silva (**) \\ Filipe J. C. Santos (***)
}

\begin{abstract}
Grave goods from the Early Iron Age necropolis of Palhais offers a unique opportunity to study the metallurgy introduced in Southern Portugal by Orientalizing influence. Metals include two sets of instruments for body grooming, an "Alcores fibula" and a belt-lock, whose typology and/or decoration shows an Orientalizing inspiration. The composition and manufacture of artefacts is determined by conventional EDXRF, Micro-EDXRF, SEM-EDS, optical microscopy and Vickers microhardness testing. Elemental compositions indicate low tin bronzes $(4.4 \pm 2.4 \%)$ evidencing significant use of scrap as inexpensive raw-material or intentional alloying with low tin amounts for economical or technological reasons. Post-casting work involved hammering and annealing operations showing that these grave goods were produced as functional artefacts. A comparison with Late Bronze Age and Early Iron Age artefacts from Southern Portugal shows that the low tin contents are common among the Phoenician bronzes. Moreover, an assessment of the co-
\end{abstract}

(*) C2TN, Campus Tecnológico e Nuclear, Instituto Superior Técnico, Universidade de Lisboa. Estrada Nacional 10 (km 139,7). 2695-066 Bobadela LRS. Portugal.

E-mails: pvalerio@ctn.ist.utl.pt; faraujo@ctn.ist.utl.pt; amsoares@ctn.ist.utl.pt

(**) CENIMAT/I3N, Centro de Investigação de Materiais, Departamento de Ciência dos Materiais, Faculdade de Ciências e Tecnologia (FCT), Universidade Nova de Lisboa. 2829-516 Monte de Caparica. Portugal. E-mail: rjcs@fct.unl.pt

(***) Rua Bairro da Moura 36, $2^{\circ} \mathrm{Dt}^{\circ}$. 3045-203 Coimbra.

Portugal. E-mail: santos.philipe@gmail.com

Received 11-IX-2012; accepted 14-IX-2012. eval metals from the Southwestern Iberian Peninsula identifies other features of the Orientalizing metallurgy, such as an increase in unalloyed coppers and leaded bronzes, which can be related to the diversification of the bronze production methods during this period.

\section{RESUMEN}

El ajuar funerario de la necrópolis de Palhais (Primera Edad del Hierro) ofrece una oportunidad única para estudiar la introducción de la metalurgia orientalizante en el sur de Portugal. Los metales incluyen objetos destinados al aseo del cuerpo, una fibula de tipo Alcores y un broche de cinturón, cuya tipología y/o decoración es de inspiración orientalizante. La composición y la cadena operativa de los artefactos se determinaron por EDXRF, Micro-EDXRF, SEM-EDS, microscopía óptica y microdureza Vickers. Las composiciones indican que se trata de bronces con bajo contenido de estaño $(4,4 \pm 2,4 \%)$, debido al uso de chatarra o al uso intencionado de pequeñas cantidades de esta materia prima por razones económicas o tecnológicas. Las microestructuras indican el trabajo del metal mediante forja y recocido, lo que apunta a que estos objetos de ajuar han sido producidos como artefactos funcionales. La comparación con los artefactos de la Edad del Bronce Final y la Primera Edad del Hierro del sur de Portugal muestra que un bajo contenido de estaño es un rasgo común entre los bronces fenicios. Además, la valoración de los metales coetáneos del suroeste de la Península Ibérica identifica otras características de la metalurgia orientalizante como el aumento de los cobres no aleados y de los bronces plomados que se pueden rela- 
cionar con la diversificación de los métodos de producción de bronce en este periodo.

Key words: Metallurgy; Bronze; Composition; Manufacture; Early Iron Age; Southern Portugal.

Palabras clave: Metalurgia; Bronce; Composición; Cadenas operativas; Primera Edad del Hierro; Sur de Portugal.

\section{INTRODUCTION}

The opening of a trench in 2008 for the 'Alvito-Pisão Irrigation Block', related to the implementation of the 'Alqueva Dam Project', revealed several negative structures at a place named Palhais (Fig. 1), not far from Beringel (Beja). The affected area was subjected to archaeological work that identified four tombs (three inhumations and one cremation) apparently connected with a burial precinct with a rectangular plant (Santos et al. 2009). These excavated structures probably belong to a larger Early Iron Age necropolis. Two inhumation tombs contained each one an adult female skeleton with a noteworthy assemblage of personal belongings, which emphasize the importance and exceptional nature of these burials in the context of the Proto-history of the Southern Por-

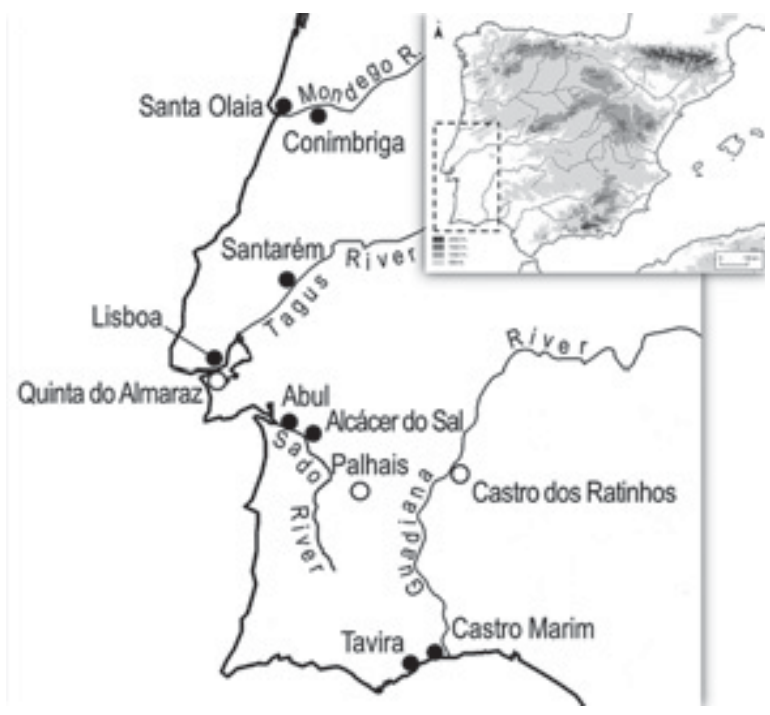

Fig. 1. Location of Palhais necropolis and other Orientalizing sites from Central and Southern Portugal (white circles correspond to sites with studied metallic artefacts). tugal. Metallic grave goods comprise five silver spherical and hollow beads and an acorn-shaped pendant, copper-based 'Alcores fibula' and decorated belt-lock and two iron knives or daggers. The metallic collection is completed by two instrument sets for body grooming that are unique among the Portuguese protohistoric record.

Grave goods involve other distinguishing materials and typologies, namely two necklaces of glass beads, a ceramic scaraboid with scroll decoration and a scarab naming Amun-Re. These artefacts emphasize the Orientalizing character of those burials but few is known about the impact of Mediterranean people in this southwestern end of Iberia or about the Phoenician-Punic trade that most probably gave rise to most of the grave goods from Palhais. The archaeological record from the Portuguese territory establishes that the Phoenician presence focuses on settlements located nearby the main estuaries and rivers, namely Castro Marim, Tavira, Abul, Alcácer do Sal, Quinta do Almaraz, Lisboa, Santarém, Santa Olaia and Conímbriga (Fig. 1). The Tagus River seems to have been the first to be used, probably as an easier route to reach the tin and gold from inland (Arruda 2005). Radiocarbon dating of stratigraphic layers of Quinta do Almaraz and Santarém dates the initial Orientalizing contacts at the end of the $9^{\text {th }}$ century BC (Barros and Soares 2004; Arruda 2005). Further to the south, the Phoenician occupation of the Sado estuary (Abul and Alcácer do Sal) and the Algarve coast (Tavira and Castro Marim) only seems to occur during the $8^{\text {th }}-7^{\text {th }}$ century $\mathrm{BC}$. The graves and material culture recovered at Palhais suggest a later chronology, around the $6^{\text {th }}$ century BC (Santos et al. 2009). This last period was characterized by a decrease of the local connections with the Mediterranean trade routes. The disruption is quite evident in the archaeological record, namely with the abandonment of some Phoenician sites such as Abul (Mayet and Silva 1992) and Santa Olaia (Arruda 1999).

Generally, the adoption of innovations by indigenous societies was a slow and selective process (Pereira 2005). This is especially true for technological improvements that could only be learned by specialized craftsmen, such as well-turned pottery or silver metallurgy. The actual knowledge about the metallurgical practices in Southern Portugal during this period of significant stimuli and shifting influences is somewhat scarce. Metallurgical

Trab. Prehist., 70, N. ${ }^{\circ}$ 2, julio-diciembre 2013, pp. 361-371, ISSN: 0082-5638

doi: $10.3989 /$ tp.2013.12119 
innovations include the silver cupellation to process argentiferous lead ores. Analytical studies have identified the silver cupellation at sites such as Quinta do Almaraz (Araújo et al. 2004) and Castelo Velho de Safara, Moura (Soares et al. 1985). The metallurgy of lead itself was also a novelty but its actual role among the copper-based metallurgy is still very poorly understood. Similarly, the local production of iron during this period is still a matter for debate. Iron artefacts only become common in the Iberian sites of the $6^{\text {th }}$ century BC (Rovira Lloréns 1993). However, the importation of iron artefacts seems to have started much earlier, during occasional pre-Orientalizing contacts of the $10^{\text {th }}$ century BC (Senna-Martinez 2000). The appearance of these superior weapons and instruments certainly had some influence on the local metallurgy of bronze, which in the future will be more associated with the production of ornaments.

This work presents a metallurgical study of the metallic grave goods from Palhais using noninvasive and microanalytical methods to establish compositional and microstructural features. The composition of the artefacts is compared with the metallurgy from Late Bronze Age (LBA) and Early Iron Age (EIA) sites to better understand the metallurgical evolution that took place inland in Southern Portugal after the Phoenician arrival at the Iberian coasts. Finally, the compositional evolution of the copper-based artefacts is correlated with the bronze production methods established for those chronological periods.

\section{METALLIC GRAVE GOODS}

The inhumation tomb 1 contained an elaborated set of toilet instruments originally connected by a large ring. The set comprises spatula, spoon ('earscoop'), scalptorium ('nail-cleaner') and another fragmented instrument of unknown type (Fig. 2). The toilet set recovered from the second inhumation tomb is more humble, containing a spoon and a scalptorium still attached by a thin metallic wire. These metallic instruments closely associated with the grooming of the body are very rare in the protohistoric record from the Iberian Peninsula. A few examples also belonging to funerary contexts can be underlined, namely those from La Joya (Garrido 1970), Los Villares (Blánquez Pérez 1990) and

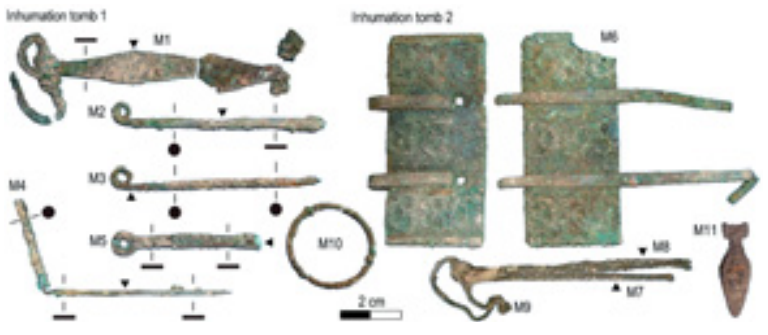

Fig. 2. Metallic grave goods from Palhais (Alcores fibula M1, spatula M2, spoon M3, scalptorium M4, unknown type M5, belt-lock M6, spoon M7, scalptorium $\mathrm{M} 8$, connection wire $\mathrm{M}$, connection ring M10 and pendant M11; with the location of the area cleaned for microanalysis).

Ampurias (Almagro Basch 1953). On the contrary, the 'Alcores type fibulae' are very common in the Southwestern Iberian Peninsula. The specimen recovered from tomb 1 at Palhais exhibits a flat bow decorated with a strip of engraved circles. This design is shared by the scalptorium but the remaining toilet instruments exhibit a thick corrosion layer that prevented the recognition of any pattern. A common decoration suggests that these artefacts were made in the same metallurgical workshop and that they were intended to be used together.

The inhumation tomb 2 contained a belt-lock with an exceptional scroll decoration of palm leaves, a motif characteristic of the Eastern Mediterranean region and symbolising fertility. A gold belt-lock almost identical was recovered at the $7^{\text {th }}-6^{\text {th }}$ century BC necropolis of Cruz del Negro (Monteagudo 1953). Additionally, the metallic grave goods from this tomb include an acorn-shaped pendant and five hollow beads. These silver artefacts originally constitute a necklace, which also included several glass beads. The acorn-shaped typology of this necklace is very usual in the Western Mediterranean region. In the Iberian Peninsula, there is an almost exact parallel in a gold necklace from La Joya (Garrido 1970) and similar pendants from Medellín (Almagro Gorbea et al. 2006) and Los Castillejos de Sanchorreja (Cerdeño et al. 1996).

\section{METHODOLOGY}

The study of the metallic grave goods from Palhais involved complementary non-invasive and mi- 
croanalytical methods to determine the composition and manufacture of the artefacts without affecting their physical integrity or archaeological significance. Non-invasive EDXRF analyses were considered semi-quantitatively because of the significant influence of the corroded layer, but were able to identify the alloy type without affecting those artefacts. Afterwards, based on the state of conservation of each artefact, it was decided which could undergo the microanalytical studies. The preparation involved the polishing of a small area $(\varnothing \sim 3-5 \mathrm{~mm})$ or the cutting of a small section that was mounted in epoxy resin and polished for microanalysis. Optical microscopy observations were used to assure that the depth of polishing was enough to eliminate the corrosion products. Micro-EDXRF was used to establish the elemental composition, while manufacture and other microstructural features were studied with SEM-EDS, optical microscopy and Vickers microhardness testing. Relative errors of the elemental analysis are lower than $2 \%$ for major elements $(\mathrm{Cu}$ and $\mathrm{Sn})$ and lower than $10 \%$ for the minor ones $(\mathrm{Pb}, \mathrm{As}$ and $\mathrm{Fe})$. The standard deviation of microhardness measurements is lower than $5 \%$. Additional details concerning the analytical techniques and methodology were previously published (Valério et al. 2012).

\section{RESULTS}

\subsection{Composition}

EDXRF analyses on the corroded surfaces of the grave goods have identified distinct metals or
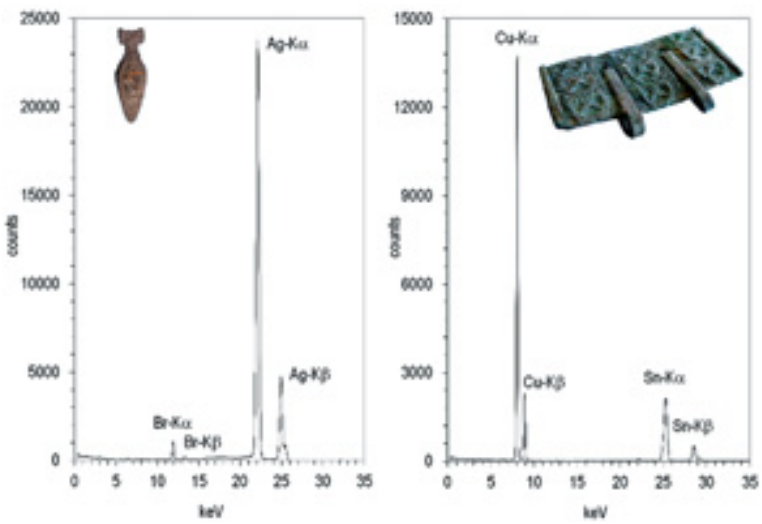

Fig. 3. EDXRF spectra of the silver pendant and the bronze belt-lock from Palhais necropolis (bromine results from the high stability of silver halogenide corrosion products commonly found in archaeological silver artefacts).

alloys (Fig. 3 and Table 1). Obtained results attest that the acorn-shaped pendant and the five hollow spherical beads are composed of silver, whereas the remaining grave goods were made with bronze alloys. These initial non-invasive analyses of the grave goods from Palhais confirm a rather diversified metallurgy comprising bronze and silver artefacts besides the iron weapons (not analysed) also recovered from those burials.

A diversified metallurgy is another feature that attests the Orientalizing nature of this necropolis, but the composition of the artefacts can give a better insight into the metal technology. The silver pendant and beads present an advanced state of corrosion that discouraged any attempt of surface cleaning. Similarly, the bronze belt-lock and connection items of toilet sets (wire and ring) were

\begin{tabular}{llcccccc}
\hline & \multicolumn{1}{c}{ Artefact } & Reference & Cu (\%) & Sn (\%) & Pb (\%) & As (\%) & Fe (\%) \\
\hline \multirow{2}{*}{ Tomb 1 } & Fibula & M1 & $93.3 \pm 0.3$ & $6.1 \pm 0.2$ & $0.12 \pm 0.02$ & $0.17 \pm 0.02$ & $0.34 \pm 0.04$ \\
& Spatula & M2 & $95.0 \pm 0.4$ & $3.2 \pm 0.3$ & $0.15 \pm 0.02$ & $0.77 \pm 0.03$ & $0.85 \pm 0.13$ \\
& Spoon & M3 & $90.4 \pm 0.4$ & $8.3 \pm 0.3$ & $0.76 \pm 0.17$ & $<0.10$ & $0.51 \pm 0.01$ \\
& Scalptorium & M4 & $95.4 \pm 0.2$ & $2.9 \pm 0.1$ & $0.14 \pm 0.05$ & $0.71 \pm 0.03$ & $0.78 \pm 0.02$ \\
& Unknown type & M5 & $93.0 \pm 0.1$ & $6.0 \pm 0.1$ & $0.33 \pm 0.01$ & $<0.10$ & $0.52 \pm 0.01$ \\
\hline \multirow{2}{*}{ Tomb 2 } & Spoon & M7 & $96.9 \pm 0.1$ & $2.2 \pm 0.1$ & $<0.10$ & $<0.10$ & $0.82 \pm 0.04$ \\
& Scalptorium & M8 & $97.0 \pm 0.1$ & $2.0 \pm 0.1$ & $<0.10$ & $<0.10$ & $0.92 \pm 0.01$ \\
\hline
\end{tabular}

Tab. 1. Results of Micro-EDXRF analyses of bronze grave goods from Palhais (average \pm standard deviation of 3 measurements).

Trab. Prehist., 70, N. ${ }^{\circ}$ 2, julio-diciembre 2013, pp. 361-371, ISSN: 0082-5638

doi: $10.3989 /$ tp.2013.12119 
not prepared for microanalysis to avoid damaging these highly corroded artefacts.

The remaining artefacts were analysed by Micro-EDXRF on surfaces cleaned of corrosion products (Tab. 1). The results established that these grave goods have somewhat low amounts of tin, namely from $2.0 \%$ to $8.3 \% \mathrm{Sn}$. In fact, the toilet instruments from inhumation tomb 2 (spoon M7: 2.2\% Sn and scalptorium M8: 2.0\% $\mathrm{Sn})$ barely reach the limit usually considered for a bronze alloy $(2 \% \mathrm{Sn})$. Additionally, these alloys have lower contents of lead and arsenic $(<0.10 \%)$ that might indicate the use of more recycled scrap or purer metallic ores. Finally, the iron content of these grave goods $(0.34 \%$ to $0.92 \% \mathrm{Fe})$ is comparable to the values usually obtained in bronzes from the EIA, such as the artefacts from Quinta do Almaraz, i.e. $0.15 \%$ to $1.3 \%$ Fe (Valério et al. 2012).

\subsection{Manufacture}

Optical microscopy observations of microstructures identified deformed equiaxial grains with annealing twins. These features indicate that the manufacture of these grave goods included both forging and annealing work (Tab. 2). Furthermore, the presence of slip bands with variable density indicates that the manufacture was completed with a more or less tough hammering, which leaves the metal in a variable strain hardened condition.

Some features such as the morphology of inclusions allow a further characterisation of the manufacture of each artefact. Sulphide inclusions are common to all microstructures and sometimes are highly elongated due to a strong narrowing of the as-cast rod. For instance, the spoon M3 and scalptorium M4 display some sulphide inclusions with a width to height ratio up to $15: 1$ suggesting an analogous and high deformation (Fig. 4). The overall deformation was certainly attained by several cycles of forging and annealing because an attempt of this thickness reduction at once would produce cracks making the material unusable. The different grain size $(\sim 10-100 \mu \mathrm{m})$ of the artefacts analysed is also very enlightening. Smaller grains such as the ones from the scalptorium M8 (Fig. 4) originate from a higher deformation and an improved control over the annealing operation (temperature and/or time) thus indicating a superior technological knowledge.

The fragmented toilet instrument was further characterised by SEM-EDS. Sulphide inclusions were found to be composed of copper and mixed copper-iron compounds originated from sulphidic impurities from the copper ore (Fig. 5). Additionally, very small lead-rich globules were found to be dispersed along the $\alpha$ matrix due to the low miscibility of lead in copper. A significant presence of these low melting point inclusions would increase the alloy fluidity although being pointless to cast these small and unadorned objects. Vickers microhardness testing of this fragmented toilet instrument revealed a relatively low hardness $(114 \pm 3 \mathrm{HV})$. This value is in agreement with the larger grain size originated by an intense annealing and a small density of slip bands from the low final deformation applied to this artefact.

\begin{tabular}{llcccc}
\hline & \multicolumn{1}{c}{ Artefact } & Reference & Phases & Inclusions & Post-casting work \\
\hline Tomb 1 & Fibula & M1 & $\alpha$ & sulphides & $(\mathrm{F}+\mathrm{A})+\mathrm{FF}$ \\
& Spatula & $\mathrm{M} 2$ & $\alpha$ & sulphides & $(\mathrm{F}+\mathrm{A})+\mathrm{FF}$ \\
& Spoon & $\mathrm{M} 3$ & $\alpha$ & sulphides & $(\mathrm{F}+\mathrm{A})+\mathrm{FF}$ \\
& Scalptorium & $\mathrm{M} 4$ & $\alpha$ & sulphides & $(\mathrm{F}+\mathrm{A})+\mathrm{FF}$ \\
& Unknown type & $\mathrm{M} 5$ & $\alpha$ & sulphides & $(\mathrm{F}+\mathrm{A})+\mathrm{FF}$ \\
\hline Tomb 2 & Spoon & $\mathrm{M} 7$ & $\alpha$ & sulphides & $(\mathrm{F}+\mathrm{A})+\mathrm{FF}$ \\
& Scalptorium & $\mathrm{M} 8$ & $\alpha$ & sulphides & $(\mathrm{F}+\mathrm{A})+\mathrm{FF}$ \\
\hline
\end{tabular}

Tab. 2. Results of optical microscopy obervations of bronze grave goods from Palhais (F: forging; A: annealing; FF: final forging; $\alpha$ : high amount; $\alpha$ : low amount). 

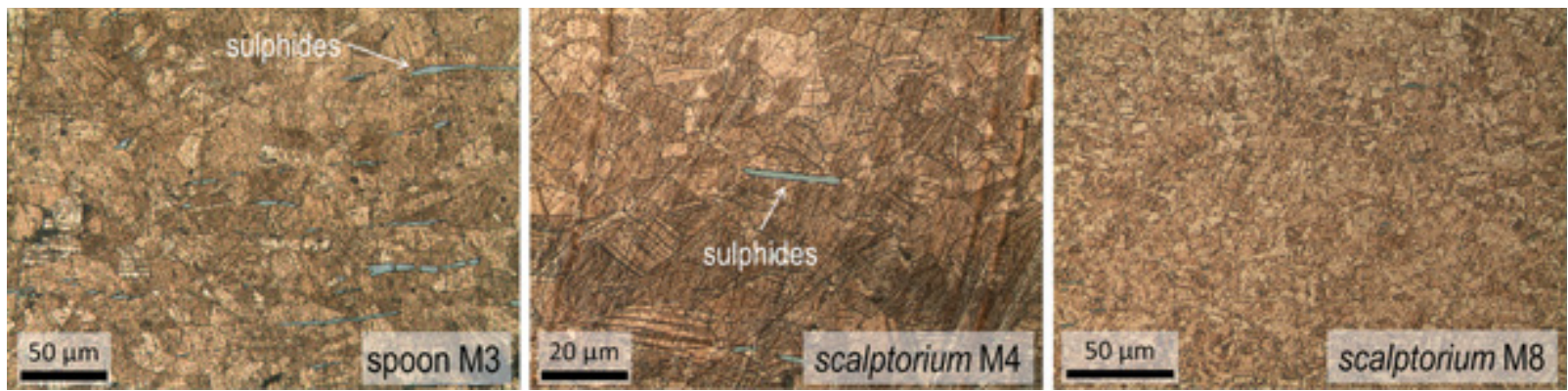

Fig. 4. Optical microscopy images of toilet instruments from Palhais (bright field, etched).

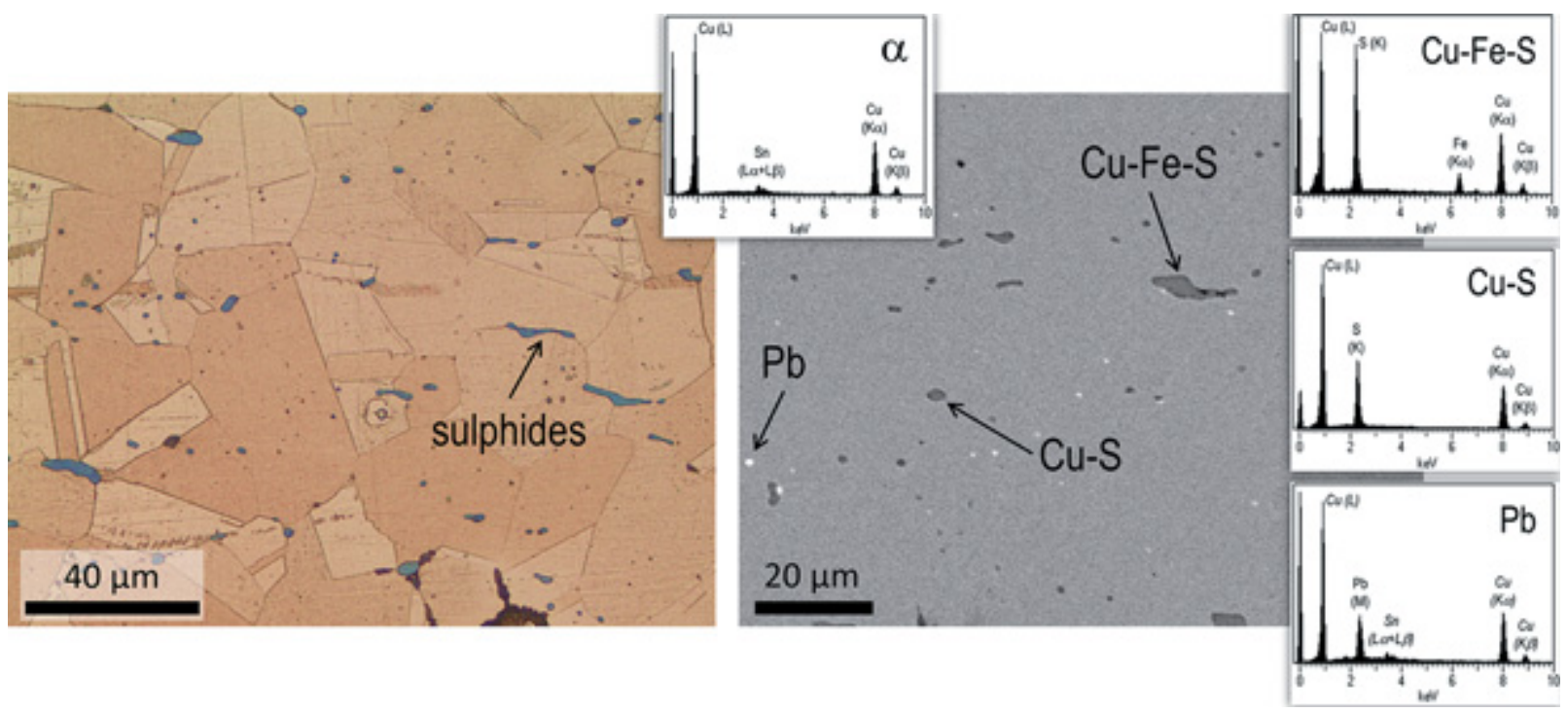

Fig. 5. Optical microscopy and SEM-BSE image of fragmented toilet instrument M5 from Palhais together with EDS spectra of the a phase, $\mathrm{Cu}-\mathrm{Fe}-\mathrm{S}, \mathrm{Cu}-\mathrm{S}$ and $\mathrm{Pb}$-rich inclusions ( $\mathrm{Cu}$ and $\mathrm{Sn}$ are present because $\mathrm{Pb}$-rich globule is smaller than the analysis spot).

The microstructures of the bronze grave goods of Palhais evidence the suitable technological expertise of those ancient metallurgists. Despite being mostly plain tools, these artefacts were manufactured with an extended operational procedure involving several thermomechanical cycles. Moreover, the microstructures evidence a similar manufacture procedure with somewhat different operational conditions (overall deformation, final hammering and annealing temperature and/or time) as expected of an unstandardized protohistoric metallurgy very dependent on the skill of each metallurgist.

\section{THE "ORIENTALIZING EFFECT"}

The most distinctive feature of the copper-based grave goods from Palhais is the alloy composition bronzes with low tin content together with a relatively high amount of iron impurities. A bronze alloy with a minor content of tin presents low castability, reduced strength and less capability to workhardening through hammering (Tylecote 1990). Furthermore, it has a distinctive reddish colour that easily distinguishes it from the bronzes richer in tin (Fang and McDonnell 2011). Technologically, low tin bronzes can be explained by 
the melting of bronze scrap instead of the alloying of copper and tin in suitable proportions. The preferential oxidation of tin over copper during the melting produces the depletion: experimental trials showed that a bronze with $10 \%$ tin will be reduced to about 3\% after a few recycling operations (Sarabia 1992). Culturally, the occurrence of low tin bronzes is often attributed to difficulties in the tin supply. Several examples can be found in prehistoric collections from Central Europe, namely from Italy (Giumlia-Mair 2005), Slovenia (Trampuz-Orel et al. 1991) or the Caucasus (Pike 2002). In our case, a possible explanation for the composition of those simple instruments, for which mechanical properties were not very important, would be related with the use of more inexpensive and accessible scrap materials. This hypothesis is also supported by the absence of known problems with the supply of tin to this region of the Portuguese territory.

The content of iron impurities in ancient bronzes is considered a valuable indicator of the smelting process (Craddock and Meeks 1987). The absence of a strong reducing atmosphere during smelting prevents the incorporation in the metallic bath of the iron impurities from the ore. In the Iberian Peninsula, ancient smelting operations were conducted in open ceramic vases, i.e. smelting crucibles, which were specially adapted to process high grade metallic ores and were often used until pre-Roman times (Rovira and Montero 2003). These smelting crucibles worked with slightly reducing atmospheres thus being thought to be responsible by the low iron content of the majority of pre-Orientalizing bronzes.

The copper-based artefacts from the $9^{\text {th }}-8^{\text {th }}$ century BC settlement of Castro dos Ratinhos (Moura) can be considered representative of the initial stages of the EIA metallurgy in the southern Portuguese territory. The metallic collection from this inland settlement displays a metallurgy mostly based on binary bronzes with suitable tin contents, i.e. $10.1 \pm 2.5 \% \mathrm{Sn}, \mathrm{n}=37$ (Valério et al. 2010). This metallurgical tradition seems to have been inherited from the preOrientalizing period because LBA artefacts of the southern Portuguese territory show similar characteristics. The collection of artefacts from Entre Águas 5 (Serpa), Baleizão (Beja), Santa Margarida (Serpa), Salsa 3 (Serpa) and Quinta do Marcelo (Almada) is mostly composed by binary bronzes with tin contents around 10\% $(9.8 \pm 2.3 \% \mathrm{Sn}, \mathrm{n}=27)(1)$.

The impact on metallurgy brought by Orientalizing people is quite evident in the Phoenician settlement of Quinta do Almaraz (Almada). The $9^{\text {th }}-7^{\text {th }}$ century BC metallic collection from this coastal site presents a significant amount of copper artefacts and a few leaded bronzes. Nevertheless, the binary bronzes remain the most common alloy at Quinta do Almaraz but are much poorer in tin $(5.4 \pm 2.0 \% \mathrm{Sn}, \mathrm{n}=15$, Valério et al. 2012) exhibiting an average value approximately half of the above mentioned collections. Moreover, the iron impurities of the metallic artefacts from Quinta do Almaraz are much higher $(0.15 \%$ to $1.3 \% \mathrm{Fe})$ than the 'indigenous' collections (mostly $<0.05 \%$ $\mathrm{Fe})$. Actually, the tin and iron contents of EIA artefacts from the southern Portuguese territory clearly distinguish the indigenous from the Orientalizing metallurgy. Furthermore, the composition of the grave goods from Palhais clearly includes them among the Orientalizing tradition (Fig. 6). These materials constitute the first studied proof of the arrival of this Orientalizing bronze metallurgy at the inland territory of Southern Portugal. A different question is the foreign or local manufacture of these grave goods. Uncommon metallic typologies, such as the toilet sets, together with the connection with clearly imported materials, such as the glass beads, suggest trading with other Mediterranean regions. However, the composition of these metals agrees with the coeval metallurgy in this region, therefore they could be local copies of foreign models. Either way, these grave goods are characteristic of the metallurgy in Southern Portugal during the EIA.

The diversification of the copper-based metallurgy during this period is also observed in other areas of the Southwestern Iberian Peninsula. The hoard of Ría de Huelva typifies the LBA metallurgical tradition being composed mainly by binary bronzes with suitable tin contents $(11.0 \pm 3.2 \%$, $\mathrm{n}=387$, Rovira 1995) similarly to the coeval collections from Southern Portugal. On the contrary, EIA collections such as El Risco and El Torrejón de Abajo (Cáceres) (Gómez Ramos and Rovira

(1) Valério, P. 2012: "Archaeometallurgical study of pre and protohistoric production remains and artefacts from Southern Portugal". Departamento de Conservação e Restauro, Faculdade de Ciências e Tecnologia, Universidade Nova de Lisboa ( $\mathrm{PhD}$ Thesis). 


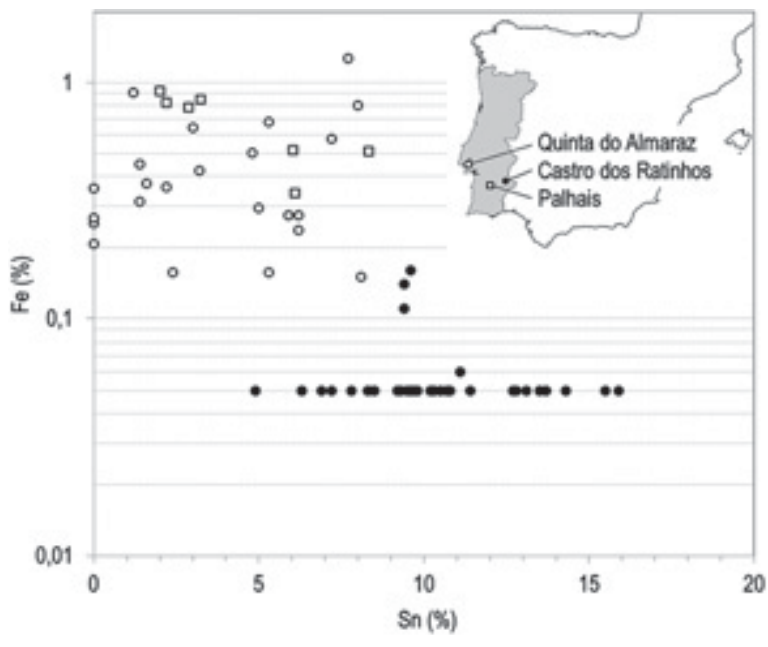

Fig. 6. Tin and iron contents of Early Iron Age artefacts from Southern Portugal: Castro dos Ratinhos (Valério et al. 2010), Quinta do Almaraz (Valério et al. 2012) and Palhais (this work).

Lloréns 2001), Medellín (Badajoz) (Montero Ruiz et al. 2003), El Palomar (Badajoz) (Rovira et al. 2005), Talavera la Vieja (Cáceres) (Montero Ruiz and Rovira Llorens 2006), Cancho Roano (Badajoz) (Montero Ruiz et al. 2003) and Morro de Mezquitilla (Málaga) (Giumlia-Mair 1992) present a significant presence of unalloyed copper and/or leaded bronze artefacts. The type of artefacts, including their function and manufacture, as well as the raw materials available on each region, has obviously an influence on the alloys produced. Cancho Roano is a good example of the dependence of the alloying practices on the manufacture since it presents a high proportion of leaded bronzes due to a significant incidence of 'as-cast' statuary items (Montero Ruiz et al. 2003). Another significant relationship can be found at Morro de Mezquitilla where minor objects (rods and fragments of small tools) and ornaments (fibulae and pins) show different alloying practices: the first group presents a higher use of unalloyed copper and bronzes with lower amounts of tin and lead (Giumlia-Mair 1992). A different situation occurs at El Risco whose artefacts are mostly binary and leaded bronzes while copper is almost absent. Moreover, the leaded bronzes already occur during the LBA despite presenting less importance that throughout the following period (Gómez Ramos and Rovira Lloréns 2001). Apparently, regardless of the particularities of each site there is a general trend to increase the use of copper and leaded bronzes in the Southwestern Iberian Peninsula during the Orientalizing period. This can be generalized to the rest of the Iberian Peninsula, where Galicia has the higher amounts of lead following the LBA Atlantic tradition (Rovira Lloréns 1993). Concerning the binary bronzes, those SW EIA collections generally present an extended variability in the amount of tin, while Talavera la Vieja and Cancho Roano show somewhat reduced tin contents that are closer to the metallurgy from Palhais and Quinta do Almaraz (Fig. 7). The reduction of the tin contents seems to be generalized to other Iberian areas with significant Phoenician influence, namely Andalusia, Levante and South Meseta (Rovira Lloréns 1993).

The increased occurrence of different copperbased alloys among the archaeological record from latter sites suggests a diversification of the bronze production methods, which seems to agree with the few studied evidences. In the Iberian Peninsula, the LBA bronze slags seem to indicate that bronze was usually produced by the co-smelting of copper and tin ores (Rovira 2007; Figueiredo et al. 2010). Modern smelting experiments using an open crucible filled with mixed copper ore, cassiterite and charcoal were able to produce metal with the help

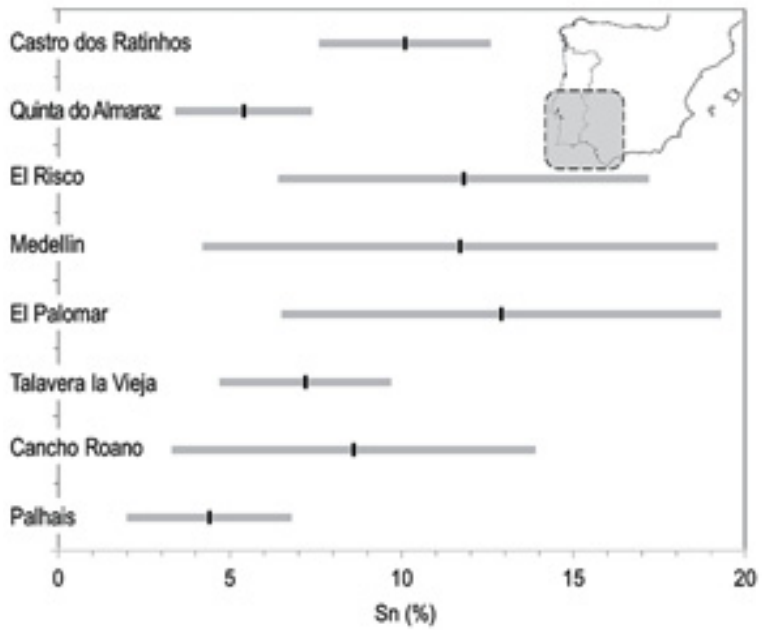

Fig. 7. Tin content (average \pm standard deviation) of Early Iron Age binary bronze artefacts from Southwestern Iberian Peninsula: Castro dos Ratinhos (Valério et al. 2010), Quinta do Almaraz (Valério et al. 2012), El Risco (Gómez Ramos and Rovira Llorens 2001), Medellin (Montero Ruiz et al. 2003), El Palomar (Rovira et al. 2005), Talavera la Vieja (Montero Ruiz and Rovira Llorens 2006), Cancho Roano (Montero Ruiz et al. 2003) and Palhais (this work).

Trab. Prehist., 70, N. ${ }^{\circ}$ 2, julio-diciembre 2013, pp. 361-371, ISSN: 0082-5638

doi: $10.3989 /$ tp.2013.12119 
of a couple of tuyeres (Rovira et al. 2009). The metallic prills formed among the slag were handpicked and melted in a second crucible to obtain a bronze ingot. In Southern Portugal, a recent study involving metallurgical remains from Entre Águas 5 (Serpa) also indicated the production of bronze by the direct reduction of oxide copper ores with cassiterite (Valério et al. 2013). This method of bronze production would result on a metallurgy with a normal-like distribution of the tin content, together with a variable range of the alloying element, according to the metallurgist technological expertise, ore composition and co-smelting conditions. Actually, this type of distribution corresponds to the observed in LBA (Entre Águas 5, Baleizão, Santa Margarida, Salsa 3 and Quinta do Marcelo) and indigenous EIA (Castro dos Ratinhos) collections from Southern Portugal (Fig. 8).

Alternatively, bronze can be obtained using the cementation of metallic copper with cassiterite or by alloying metallic copper with tin. Some indications of the cementation process were identified in contexts belonging to the transition of the
LBA to the EIA at Gusendo de los Oteros (León), while the earliest known indication of the melting of copper with tin belongs to an $8^{\text {th }}-7^{\text {th }}$ century BC context from Carmona (Sevilla) (Rovira 2007). Alloying the two metals provides an improved control over the tin content of the alloy, either for mechanical, colouring, economical or other reasons. Additionally, the overall use of several production methods, together with a probable increase of bronze scrap remelting, would explain the more diversified metallurgy such as the one observed in EIA collections (Quinta do Almaraz and Palhais) from Southern Portugal (Fig. 8).

\section{CONCLUSIONS}

The metallic grave goods of Palhais necropolis are representative of a period characterized by a diversified metallurgy, as shown the occurrence of bronze, silver and iron artefacts. Additionally, bronze artefacts exhibit a low amount of tin that
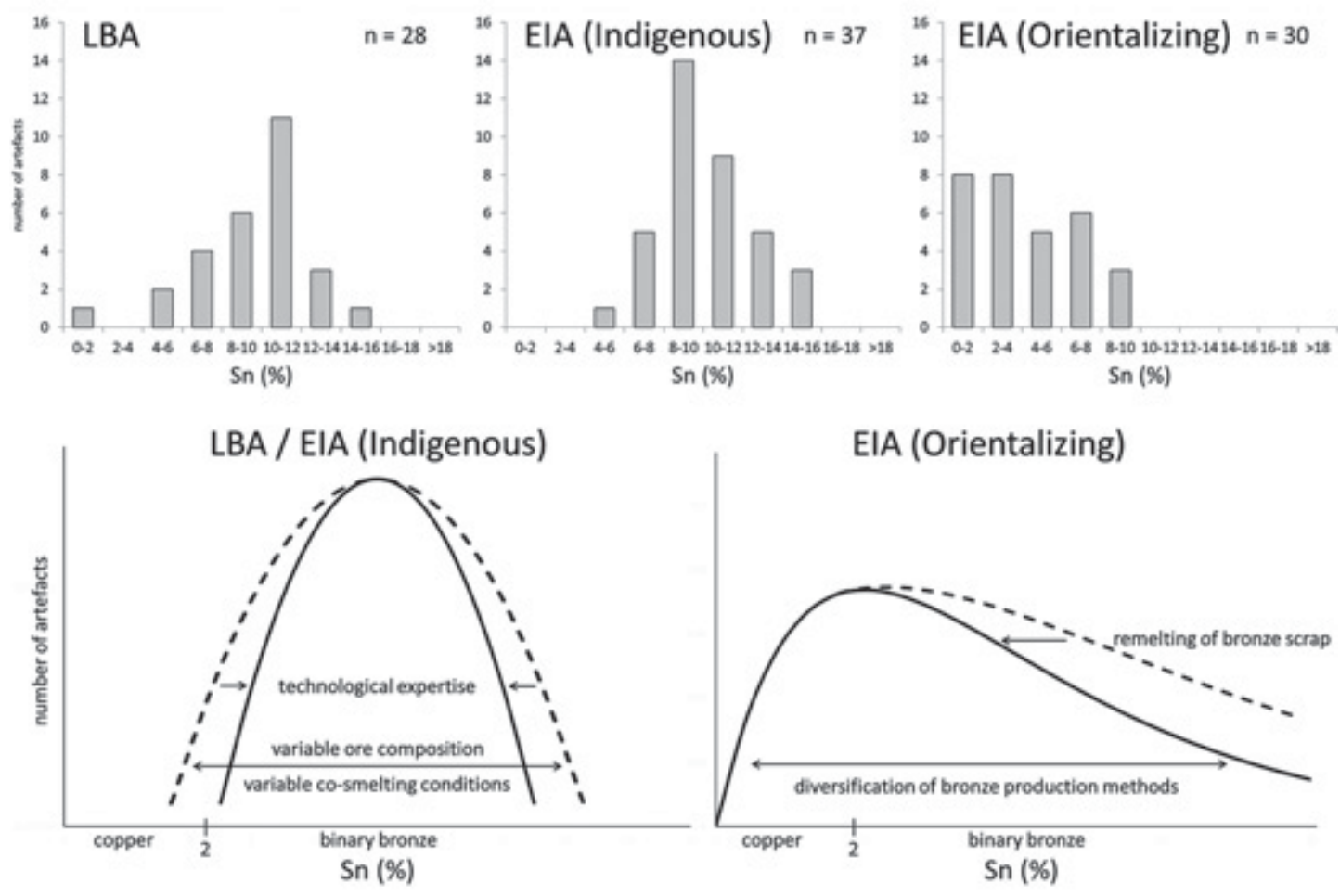

Fig. 8. Tin content of LBA, EIA (Indigenous) and EIA (Orientalizing) copper-based artefacts from Southern Portugal and corresponding models resulting from the different bronze production methods. 
is concordant with the increased variability of the bronze alloys found among the Orientalizing sites. In this particular case, the poor bronze alloys can be explained by the use of bronze scrap as an inexpensive raw-material. However, the intentional alloying with low amounts of tin to spare on this expensive raw-material or to obtain an alloy with a more reddish colour cannot be discarded. In either case, the manufacturing procedures certainly involved much effort comprising the combined benefits of hammering and annealing. The careful manufacture suggests that these objects were not produced as burial offerings instead being functional items that probably were used by those women throughout their lives.

A metallurgical diversification was previously identified in other areas of the Southwestern Iberian Peninsula with strong connexions with the Mediterranean region, but only now was recognised in the inland region of Portugal. The higher levels of iron suggest the use of more efficient smelting operations, which is another characteristic of the Early Iron Age metallurgy. The use of different methods of bronze production (cosmelting, cementation, alloying and remelting of bronze scrap) during this period could explain the diversity of alloys of Orientalizing and Post-Orientalizing sites, but additional studies regarding slags and other metallurgical remains recovered in well dated archaeological contexts are crucial to better clarify this assumption.

\section{ACKNOWLEDGEMENTS}

This work was carried out in the framework of the project "Early Metallurgy in the Portuguese Territory" - EarlyMetal (PTDC/HIS/ ARQ/110442/2008) financed by the Portuguese Science Foundation. CENIMAT/I3N gratefully acknowledges the funding through the Strategic Project PEst-C/CTM/LA0025/2013.

\section{BIBLIOGRAPHY}

Almagro Basch, M. 1953: Las Necrópolis de Ampurias. 1. Introducción y Necrópolis Griegas. Seix y Barral. Barcelona.

Almagro Gorbea, M.; Jiménez Ávila, J.; Lorrio, A. J.; Mederos, A. and Torres, M. 2006: La necrópolis de
Medellín. I. La Excavacion y sus hallazgos. Bibliotheca Archaeologica Hispana XXVI, Real Academia de la Historia. Madrid.

Araújo, M. F.; Barros, L.; Teixeira, A. C. and Melo, A. A. 2004: "EDXRF study of prehistoric artefacts from Quinta do Almaraz (Cacilhas, Portugal)". Nuclear Instruments and Methods in Physics Research B 213 (1): 741-746.

Arruda, A. M. 1999: Los Fenicios en Portugal. Fenicios y mundo indigena en el centro y sur de Portugal (siglos VIII-VI a.C.). Cuadernos de Arqueología Mediterránea 5-6, Universidad Pompeu Fabra. Barcelona.

Arruda, A. M. 2005: “O $1^{\circ}$ Milénio a.n.e. no centro e no sul de Portugal: leituras possíveis no início de um novo século". O Arqueólogo Português IV, 23: 9-156.

Barros, L. and Soares, A. M. M. 2004: "Cronologia absoluta para a ocupação Orientalizante da Quinta do Almaraz no estuário do Tejo (Almada, Portugal)". O Arqueólogo Português IV, 22: 333-352.

Blánquez Pérez, J. 1990: La Formación del Mundo Ibérico en el Sureste de la Meseta. Instituto de Estudios Albacetences. Albacete.

Cerdeño, M.; García-Huerta, R.; Baquedano, I. and Cabanes, E. 1996: "Contactos interior-zonas costeras durante la Edad del Hierro: los focos del noreste y suroeste meseteños". In T. Chapa and M. A. Querol (eds.): Homenaje al profesor Manuel FernándezMiranda, Complutum Extra 6 (1), Universidad Complutense. Madrid: 287-312.

Craddock, P. T. and Meeks, N. D. 1987: "Iron in ancient copper”. Archaeometry 29 (2): 187-204.

Fang, J. L. and McDonnell, G. 2011: "Colour of copper alloys". Historical Metallurgy 45 (1): 52-61.

Figueiredo, E.; Silva, R. J. C.; Fernandes, F. M. B.; Araújo, M. F.; Senna-Martinez, J. C. and Vaz, J. L. I. 2010: "Smelting and recycling evidences from the Late Bronze Age habitat site of Baiões (Viseu, Portugal)". Journal of Archaeological Science 37 (7): 1623-1634.

Garrido, J. P. 1970: Excavaciones en la Necrópolis de la Joya, Huelva ( $1^{a}$ y $2^{a}$ Campañas). Excavaciones Arqueológicas en España 71. Madrid.

Giumlia-Mair, A. R. 2005: "Copper and copper alloys in the southeastern Alps: an overview". Archaeometry 47 (2): 275-292.

Giumlia-Mair, A. R. 1992: "The composition of copper-based small finds from a west Phoenician settlement site and from Nimrud compared with that of contemporary Mediterranean small finds". Archaeometry 34 (1): 107-119.

Gómez Ramos, P. and Rovira Lloréns, S. 2001: “Aspectos metalúrgicos de 'El Risco' y de 'El Torrejón de Abajo' (Cáceres)”. In J. J. Enríquez Navascués, A. Rodríguez Días and I. Pavón Sodevilla (eds.): El Risco Excavación de Urgencia en Sierra de Fuentes (Cáceres). 1991-1993. Memorias de Arqueología Extremeña 4, Editora Regional de Extremadura. Mérida: 195-213. 
Mayet, F. and Silva, C. T. 1992: "Abul: um estabelecimento Orientalizante do Século VII a.C. no baixo vale do Sado". Setúbal Arqueológica 9-10: 315-333.

Monteagudo, L. 1953: "Album gráfico de Carmona por G. Bonsor”. Archivo Español de Arqueología XXVI: $350-370$.

Montero Ruiz, I.; Gómez Ramos, P. and Rovira Llorens, S. 2003: "Aspectos de la metalurgia orientalizante en Cancho Roano". In S. Celestino Pérez (ed.): Cancho Roano IX. Los Materiales Arqueológicos II, Junta de Extremadura. Badajoz: 195-210.

Montero Ruiz, I. and Rovira Llorens, S. 2006: "Comentarios sobre las composiciones de los metales del conjunto". In J. Jiménez Ávila (ed.): El Conjunto Orientalizante de Talavera la Vieja (Cáceres). Junta de Extremadura. Cáceres: 109-114.

Pereira Sieso, J. 2005: "Entre la fascinación y el rechazo: la aculturación entre las propuestas de interpretación del periodo Orientalizante". In S. Celestino Pérez y J. Jiménez Ávila (eds.): El Periodo Orientalizante. Actas del III Simposio Internacional de Mérida: Protohistoria del Mediterráneo Occidental (Mérida 2005). Anejos de Archivo Español de Arqueología XXXV, CSIC. Madrid: 167-187.

Pike, A. W. G. 2002: "Analysis of caucasian metalwork - the use of antimonal, arsenical and tin bronze in the Late Bronze Age". In J. Curtis and M. Kruszynnski (eds.): Ancient Caucasian and Related Materials in the British Museum. The British Museum. London: 89-92.

Rovira Lloréns, S. 1993: "La metalurgia de la Edad del Hierro en la Península Ibérica: una síntesis introductoria". In A. Arana Castillo, A. M. Muñoz Amilibia, S. Ramallo Asensio and $\mathrm{M}^{\mathrm{a}} \mathrm{M}$. Ros Sala (eds.): Metalurgia en la Península Ibérica durante el primer milenio a.C. Estado actual de la investigación. Cuadernos 65, Universidad de Murcia. Murcia: 45-70.

Rovira, S. 1995: "Estudio arqueometalúrgico del depósito de la Ría de Huelva.” In M. Ruiz-Gálvez Priego (ed.): Ritos de paso y puntos de paso. La Ría de Huelva en el mundo del Bronce Final europeo. Complutum Extra 5, Universidad Complutense. Madrid: $33-57$.

Rovira, S. 2007: "La producción de bronces en la Prehistoria”. In J. Molera Marimon, J. Farjas Silva, P. Roura Grabulosa and T. Pradell Cara (eds.): Avances en Arqueometría 2005. Actas del VI Congresso Ibérico de Arqueometría (Girona): 21-35. Girona.

Rovira, S. and Montero, I. 2003: "Natural tin-bronze alloy in Iberian Peninsula metallurgy: potentiality and reality". In A. Giumlia-Mair and F. Lo Schiavo (eds.): The Problem of Early Tin. British Archaeological Reports, International Series 1199, Archaeopress. Oxford: 15-22.

Rovira, S.; Montero, I.; Ortega J. and Jiménez Ávila, J. 2005: "Bronce y trabajo del bronce en el poblado
Orientalizante de 'El Palomar' (Oliva de Mérida, Badajoz)". In S. Celestino Pérez y J. Jiménez Ávila (eds.): El Periodo Orientalizante. Actas del III Simposio Internacional de Mérida: Protohistoria del Mediterráneo Occidental (Mérida 2005). Anejos de Archivo Español de Arqueología XXXV, CSIC. Madrid: $1231-1240$.

Rovira, S.; Montero Ruiz, I. and Renzi, M. 2009: "Experimental co-smelting to copper-tin alloys". In T. L. Kienlin and B. W. Roberts (eds.): Metals and Societies. Studies in Honour of Barbara S. Ottaway. Universitätsforschungen zur Prähistorischen Archäologie 169. Bonn: 407-414.

Santos, F. J. C.; Antunes, A. S.; Grilo, C. and Deus, M. 2009: "A necrópole da I Idade do Ferro de Palhais (Beringel, Beja). Resultados preliminares de uma intervenção de emergência no Baixo-Alentejo". In J. A. Pérez Macías and E. R. Bomba (eds.): IV Encuentro de Arqueología del Suroeste Peninsular (Huelva 2008): 746-804. Huelva.

Sarabia, F. J. 1992: "Arqueología experimental. La fundición de bronce en la Prehistoria reciente". Revista de Arqueología 130: 12-22.

Senna-Martinez, J.C. 2000: “O problema dos primeiros ferros peninsulares em contextos do Bronze Final da orla atlântica: os dados do 'Outeiro dos Castelos de Beijós' (Carregal do Sal)". Trabalhos de Arqueologia da Estudo Arqueológico da Bacia do Mondego 6: 43-60.

Soares, A. M. M.; Araújo, M. F. and Cabral, J. M. P. 1985: "O Castelo Velho de Safara: vestígios da prática da metalurgia". Arqueologia 11: 87-94.

Trampuz-Orel, N.; Milic, Z.; Hudnik, V. and Orel B. 1991: "Inductively coupled plasma-atomic emission- spectroscopy analysis of metals from Late Bronze Age hoards in Slovenia". Archaeometry 33: 267-277.

Tylecote, R. F. 1990: The Prehistory of Metallurgy in the British Isles. The Institute of Metals. London.

Valério, P.; Soares, A. M. M,; Silva, R. J. C.; Araújo, M. F.; Rebelo, P.; Neto, N.; Santos, R. and Fontes, T. 2013: "Bronze production in Southwestern Iberian Peninsula: the Late Bronze Age metallurgical workshop from Entre Águas 5 (Portugal)". Journal of Archaeological Science 40 (1): 439-451.

Valério, P.; Silva, R. J. C.; Araújo, M. F.; Soares, A. M. M. and Barros, L. 2012: "A multianalytical approach to study the Phoenician bronze technology in the Iberian Peninsula - a view from Quinta do Almaraz". Materials Characterization 67: 74-82.

Valério, P.; Silva, R. J. C.; Monge Soares, A. M.; Araújo, M. F.; Braz Fernandes, F. M.; Silva, A. C. and Berrocal-Rangel, L. 2010: "Technological continuity in Early Iron Age bronze metallurgy at the South- Western Iberian Peninsula - a sight from Castro dos Ratinhos". Journal of Archaeological Science 37 (8): 1811-1819. 